\title{
Pindolol acts as beta-adrenoceptor agonist in orthostatic hypotension: therapeutic implications
}

\author{
A J MAN IN 'T VELD, M A D H SCHALEKAMP
}

\begin{abstract}
Three bedridden patients with severe orthostatic hypotension due to chronic autonomic failure were treated with pindolol (15 mg/day), a beta-adrenoceptor antagonist with partial agonist activity. While taking this drug the patients were free of orthostatic symptoms: they could walk, and standing blood pressure was maintained above $90 / 50 \mathrm{~mm} \mathrm{Hg}$. Supine heart rate rose during treatment by 12-21 beats/minute, and stroke volume and cardiac output by $12-24 \mathrm{ml}$ and $1.5-3 \cdot 1 \mathrm{l} / \mathrm{min}$ respectively. Supine blood pressure rose by $21-68 \mathrm{~mm} \mathrm{Hg}$ systolic and 14-49 mm Hg diastolic.

Pindolol $15 \mathrm{mg} /$ day was therapeutically effective in these three patients with severe orthostatic hypotension due to chronic autonomic failure. Further studies in a larger series of patients are needed to confirm this result.
\end{abstract}

\section{Introduction}

Orthostatic hypotension is the most incapacitating feature in patients with chronic autonomic failure. Standing upright causes pooling of blood in the extremities and a fall in central venous pressure, cardiac output, and arterial pressure. Normally, these haemodynamic changes are counteracted by baroreceptormediated reflex responses leading to arteriolar vasoconstriction, augmented venomotor tone, enhanced myocardial contractility, and increased heart rate. These cardiovascular adjustments to gravitational stress are insufficient in autonomic failure.

Most patients with chronic autonomic failure have low concentrations of circulating noradrenaline, which rise little, if at all, on head-up tilting. ${ }^{2}$ Supersensitivity to catecholamines in these patients has been reported. ${ }^{2-5}$ In addition, some evidence

\footnotetext{
Department of Internal Medicine I, University Hospital Dijkzigt, Erasmus University, Rotterdam, The Netherlands

A J MAN IN 'T VELD, MD, senior registrar

M A D H SCHALEKAMP, MD, PHD, professor of medicine
}

exists that myocardial contractility is impaired in chronic autonomic failure. ${ }^{6}$ The combination of these abnormalities suggests that beta-adrenoceptor-blocking drugs with intrinsic sympathomimetic activity might have therapeutic effects in this disorder. When receptor occupancy is low a full antagonist would have little or no effect while a partial beta-adrenoceptor antagonist would act as a full agonist. Moreover, any agonist effect would be enhanced by the presence of denervation hypersensitivity and the absence of inhibitory baroreflex responses. These considerations prompted us to assess in three patients the effects of pindolol, the only beta-adrenoceptorblocking drug with appreciable intrinsic sympathomimetic activity currently available.

\section{Patients and methods}

Case 1-A woman aged 25 years presented at our clinic in 1976 with acute autonomic neuropathy. ${ }^{7}$ Severe orthostatic hypotension was the most disabling feature of her disease. Autonomic failure secondary to diabetes mellitus, chronic renal failure, amyloidosis, syphilis, or drugs was excluded. She had no signs of cerebellar degeneration, pyramidal features, or Parkinsonism.

Case 2-A man aged 40 years presented in 1978 with complaints of sexual impotence. Later he develcped orthostatic hypotension, diarrhoea, urine retention, and muscle weakness. Amyloid material was found in biopsy specimens of the liver, rectal mucosa, and sural nerve. His mother had died after a similar disease and primary amyloidosis had been diagnosed after necropsy. Secondary forms of amyloidosis were excluded in our patient, confirming the diagnosis of primary hereditary amyloidosis.

Case 3-A man aged 64 years had had muscle weakness and autonomic failure for four years owing to amyloidosis accompanying a multiple myeloma. Amyloid material was found in biopsy specimens of liver, kidney, and rectal mucosa.

All the patients gave their informed consent after the possible therapeutic consequences of the investigations had been explained. Studies were performed after the patients had been admitted to the metabolic ward. The diet contained $100 \mathrm{mmol}(\mathrm{mEq})$ sodium, and the patients had not taken any drugs for at least three weeks before admission.

During diagnostic procedures radial artery pressure was measured continuously. For follow-up studies blood pressure was measured with the London School of Hygiene sphygmomanometer (Model MK4). 
The diagnosis of orthostatic hypotension owing to autonomic failure was validated in each patient by $60^{\circ}$ head-up tilting on a tilt table and by the Valsalva manoeuvre (table). Pressor responses to mental stress (mental arithmetic), a painful cold stimulus (immersion of a hand in water at $4^{\circ} \mathrm{C}$ for one minute), phenylephrine (50 $\mu$ g intravenously), and tyramine ( $5 \mathrm{mg}$ intravenously) were investigated in an attempt to localise the defect in the baroreflex arc. The depressor response to hyperventilation (one minute) and the cardioaccelerator response to atropine ( $1 \mathrm{mg}$ intravenously) were also investigated. Plasma noradrenaline concentration was measured by a sensitive radioenzymatic technique. ${ }^{8}$ Cardiac output was measured by a non-invasive radioisotope dilution method $^{9}$ before and after one week of treatment with pindolol $15 \mathrm{mg} /$ day divided over three doses.

\section{Results}

\section{TESTS OF AUTONOMIC FUNCTION}

All patients became severely hypotensive and lost consciousness within two minutes after $60^{\circ}$ head-up tilting (fig 1 ). The normal overshoot of systolic pressure in phase IV of the Valsalva response was absent (fig 2). Two patients (cases 1 and 3) showed no pressor response to stress, and plasma noradrenaline concentration was below the limit of detection-that is, below $25 \mathrm{pg} / \mathrm{ml}$. These findings indicate an efferent sympathetic lesion. ${ }^{2}{ }^{5}$ The remaining patient (case 2) showed a sharp fall in arterial pressure during hyperventilation, and plasma noradrenaline concentrations were between 60 and $140 \mathrm{pg} / \mathrm{ml}$. These results indicate afferent baroreflex denervation with relatively intact efferent sympathetic fibres. The intactness of the efferent sympathetic fibres was confirmed by pressor responses to stress and

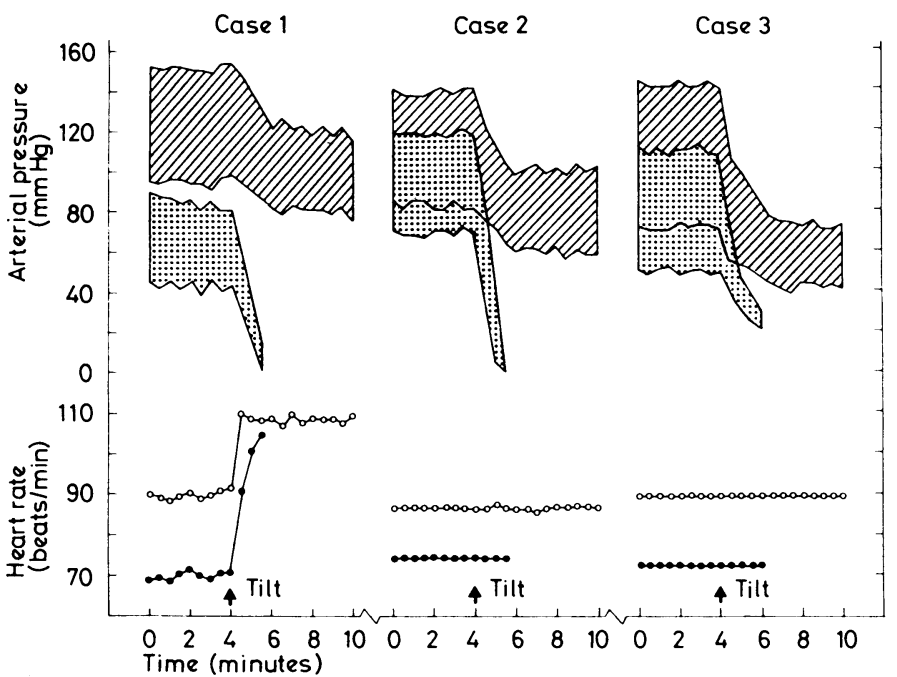

FIG 1-Effect of $60^{\circ}$ head-up tilting on arterial pressure and heart rate before (O) and after $(O)$ taking pindolol $15 \mathrm{mg} /$ day. Note absence of sinus arrhythmia and reflex tachycardia in cases 2 and 3 .

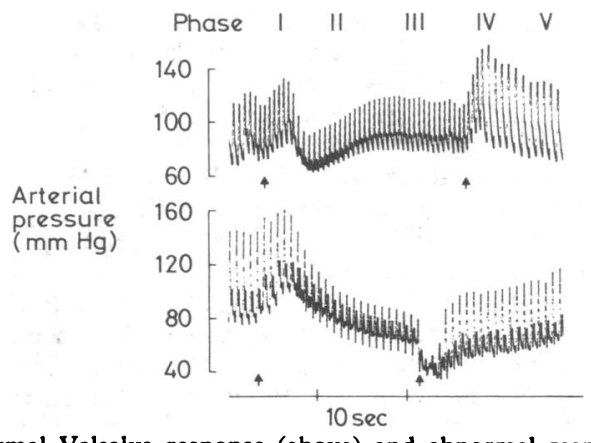

FIG 2-Normal Valsalva response (above) and abnormal response (below; obtained in case 3). Time of blowing into mercury manometer to level of $40 \mathrm{~mm} \mathrm{Hg}$ is indicated by arrows. Note absence of cardioacceleration in phases II and III and absence of systolic overshoot in phase IV in autonomic failure. tyramine and by a rise in plasma noradrenaline concentration after tyramine was given (table).

The responses to bolus injections of phenylephrine indicated various degrees of supersensitivity in each patient, which was most pronounced in cases 1 and 3. Sinus arrhythmia and cardioaccelerator responses to tilting and to atropine were absent in cases 2 and 3 (fig 1, table), indicating concomitant efferent vagal dysfunction. The presence of intact baroreflex afferents and vagal efferents in case 1 was confirmed by the onset of bradycardia after phenylephrine (table).

Thus one patient (case 1) had a lesion of the baroreflex sympathetic efferents; the second (case 2) had combined lesions of baroreflex afferents and vagal efferents; and the third had combined lesions of the baroreflex sympathetic and vagal efferents.

Results of diagnostic tests in three patients with orthostatic hypotension

\begin{tabular}{|c|c|c|c|}
\hline & Case 1 & Case 2 & Case 3 \\
\hline $\begin{array}{l}\text { Systolic overshoot in the Valsalva response } \\
\text { Pressor response to stress (mm Hg) } \\
\text { Pressor response to cold (mm Hg) }\end{array}$ & $\begin{array}{l}\text { Absent } \\
\text { Absent } \\
\text { Absent }\end{array}$ & $\begin{array}{l}\text { Absent } \\
+16 \\
+19\end{array}$ & $\begin{array}{l}\text { Absent } \\
\text { Absent } \\
\text { Absent }\end{array}$ \\
\hline $\begin{array}{l}\text { Depressor response to hyperventilation } \\
\text { (mm Hg) }\end{array}$ & Absent & -54 & Absent \\
\hline $\begin{array}{l}\text { Pressor response to phenylephrine } 50 \mu \mathrm{g} \\
\text { intravenously (mm Hg) } \\
\text { Pressor response to tyramine } 5 \mathrm{mg}\end{array}$ & +58 & +22 & +40 \\
\hline $\begin{array}{l}\text { Pressor response to tyramine } 5 \mathrm{mg} \\
\text { intravenously (mm Hg) }\end{array}$ & Absent & +20 & Absent \\
\hline $\begin{array}{l}\text { Plasma noradrenaline response to tyramine } \\
5 \mathrm{mg} \text { intravenously }(\mathrm{pg} / \mathrm{ml}) \\
\text { Cardioaccelerator response to atropine }\end{array}$ & Absent & +80 & Absent \\
\hline $\begin{array}{l}\text { Cardioaccelerator response to atropine } \\
1 \mathrm{mg} \text { intravenously (beats } / \mathrm{min} \text { ) }\end{array}$ & +56 & Absent & Absent \\
\hline $\begin{array}{l}\text { Cardiodecelerator response to phenylephrine } \\
50 \mu \mathrm{g} \text { intravenously (beats } / \mathrm{min} \text { ) }\end{array}$ & -21 & Absent & Absent \\
\hline
\end{tabular}

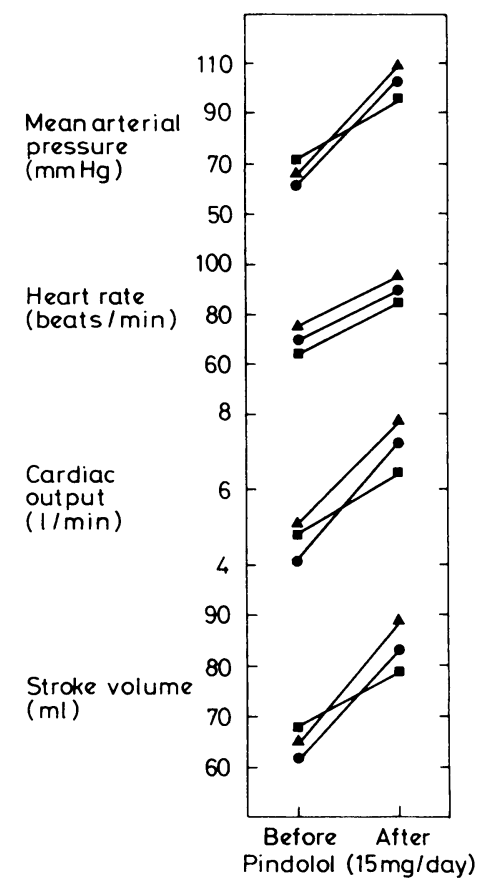

FIG 3-Effects of taking pindolol $15 \mathrm{mg} /$ day for seven days on supine systemic haemodynamic variables in chronic autonomic failure (cardiac output and stroke volume converted to $1.73 \mathrm{~m}^{2}$ body surface area). $O=$ case 1 ; $\mathbf{A}=$ case $2 ; \mathbf{a}=$ case 3

\section{TREATMENT WITH PINDOLOL}

After one day of treatment with pindolol the patients could walk and orthostatic symptoms had disappeared. After seven days haemodynamic measurements were repeated and the patients again subjected to head-up tilting with continuous monitoring of intra-arterial pressure. Resting supine heart rates had increased by 12-21 beats/min (figs 1 and 3 ) and mean arterial pressure by $26-45 \mathrm{~mm} \mathrm{Hg}$. Cardiac output was $1 \cdot 5-3 \cdot 1 \mathrm{l} / \mathrm{min}$ higher than before treatment, and stroke volume had increased by $12-24 \mathrm{ml}$. After tilting at $60^{\circ}$ mean arterial pressure fell by $20-43 \mathrm{~mm} \mathrm{Hg}$ but, in contrast with the period before pindolol, it reached a stable plateau within five minutes and none of the patients collapsed. Two patients (cases 1 and 2) were followed up for eight and 12 months respectively. The beneficial effects of pindolol 
did not wear off during follow-up, the patients remaining free of orthostatic symptoms: blood pressure during standing for 15 minutes was maintained above $90 / 50 \mathrm{~mm} \mathrm{Hg}$, while supine blood pressure was not higher than $150 / 90 \mathrm{~mm} \mathrm{Hg}$.

\section{Discussion}

The various approaches to managing severe orthostatic hypotension all have their limitations. ${ }^{5}$ Applying elastic stockings up to the waist or antigravity suits to prevent reduction of venous return when standing are of limited value and socially barely tolerable. ${ }^{510}$ Treatment with beta-adrenoceptor agonists is mostly disappointing, ${ }^{31011}$ whereas treatment with alphaadrenoceptor stimulants combined with monoamine-oxidase inhibitors is often accompanied by severe supine hypertension. ${ }^{11}$ Volume expansion with mineralocorticoid hormones is ineffective in severe cases and causes supine hypertension. ${ }^{12}{ }^{13}$ Furthermore, it carries the risk of precipitating heart failure, since chronic autonomic failure may be associated with impaired myocardial contractility. ${ }^{6}$ Low doses of mineralocorticoid hormone, which do not induce fluid retention, might enhance the vascular response to pressor amines. Perhaps such low doses might exert a beneficial effect in some cases through an increase in vascular tone. ${ }^{1214}$ Kochar and Itskovitz ${ }^{15}$ claimed that indomethacin is useful in inhibiting the formation of vasodilating prostaglandins, but this claim was later challenged. ${ }^{16}$

We found pindolol $15 \mathrm{mg} /$ day to be therapeutically effective in our three patients with severe orthostatic hypotension due to efferent or afferent lesions, or both, of the baroreflex arc. The drug had appreciable chronotropic and inotropic cardiac effects in these patients, which contrasts with observations in normal subjects. ${ }^{17}$ A substantial increase in supine blood pressure was observed in our patients, but the pressure did not reach hypertensive values. While the orthostatic drop in pressure was not prevented by pindolol, the pressure reserve was high enough to maintain adequate cerebral perfusion. Before taking pindolol the patients were bedridden; with the drug they were able to walk and did not collapse when standing for 15 minutes.

Interestingly, in view of the chronotropic effect that we observed, a patient with intractable orthostatic hypotension has successfully been treated with atrial tachypacing. ${ }^{18}$ The inotropic effect of pindolol might also be beneficial in such patients, particularly when autonomic neuropathy is associated with heart failure. Further studies in a larger series of patients are needed to confirm that pindolol is a useful alternative to the conventional treatment of orthostatic hypotension, which is often ineffective and thwarted by hazardous side effects.
This study was supported by a grant from Sandoz BV, Uden, The Netherlands.

\section{References}

${ }^{1}$ Ziegler MG, Lake CR, Kopin IJ. Deficient sympathetic nervous response in familial dysautonomia. N Engl F Med 1976;294:630-3.

2 Bannister R, Davies B, Holly E, Rosenthal T, Sever P. Defective cardiovascular reflexes and supersensitivity to sympathomimetic drugs in autonomic failure. Brain 1979;102:163-76.

3 Parks VJ, Sandison AG, Skinner SL, Whelan RF. Sympathomimetic drugs in orthostatic hypotension. Lancet $1961 ; \mathrm{i}: 1133-6$.

${ }^{4}$ Engelman K, Mueller PS, Horwitz D, Sjoerdsma A. Denervation hypersensitivity of adipose tissue in idiopathic orthostatic hypotension. Lancet $1964 ; \mathrm{ii}: 927-9$.

${ }^{5}$ Bannister R. Chronic autonomic failure with postural hypotension. Lancet 1979 ;ii:404-6.

6 Ibrahim MM, Tarazi RC, Dustan HP, Bravo EL. Idiopathic orthostatic hypotension: circulatory dynamics in chronic autonomic insufficiency. Am $\mathcal{F}$ Cardiol $1974 ; 34: 288-94$

${ }^{7}$ Hopkins A, Neville B, Bannister R. Autonomic neuropathy of acute onset. Lancet $1974 ; \mathrm{i}: 769-71$.

${ }^{8}$ Henry BP, Starman BJ, Johnson DG, Williams RH. A sensitive radioenzymatic assay for norepinephrine in tissues and plasma. Life Sci 1975; $16: 375-84$.

9 Man in 't Veld AJ, Wenting GJ, Verhoeven RP, Schalekamp MADH. Quantitative radiocardiography by single-probe counting using ${ }^{99}$ mtechnetium albumin. Neth $\mathcal{F}$ Med 1978;21:166-75.

10 Bannister R, Ardill L, Fentem P. An assessment of various methods of treatment of idiopathic orthostatic hypotension. $Q \mathcal{F}$ Med 1969;152: treatment

11 Davies B, Bannister R, Sever P. Pressor amines and monoamine-oxidase inhibitors for treatment of postural hypotension in autonomic failure. Limitations and hazards. Lancet $1978 ; \mathrm{i}:$ :172-5.

12 Chobanian AV, Volicer L, Tift CP, Gavras H, Liang CS, Faxon D. Mineralocorticoid-induced hypertension in patients with orthostatic hypotension. $N$ Engl F Med 1979;301:68-73.

${ }^{13} \mathrm{Man}$ in 't Veld AJ, Wenting GJ, De Bruyn JHB, Schalekamp MADH. Age-related differences in the long-term responses of systemic flow and resistance to mineralocorticoid excess in man. In: Stokes GS, ed. Progress in biochemical pharmacology. Vol 17. Hormones and the kidney. Basle: Karger, 1980.

14 Davies B, Bannister R, Sever P, Wilcox C. The pressor actions of noradrenaline, angiotensin II and saralasin in chronic autonomic failure treated with fludrocortisone. Br f Clin Pharmacol 1979;8:253-60.

${ }^{15}$ Kochar MS, Itskovitz HD. Treatment of idiopathic orthostatic hypotension (Shy-Drager syndrome) by indomethacin. Lancet 1978;i:1011-4.

16 Davies B, Bannister R, Hensby C, Sever PS. The pressor actions of noradrenaline and angiotensin II in chronic autonomic failure treated with indomethacin. Br f Clin Pharmacol 1980;10:223-9.

17 Svendson TL, Hartling O, Trap-Jensen J. Immediate haemodynamic effects of propranolol, practolol, pindolol and ICI 89,406 in healthy volunteers. Eur 7 Clin Pharmacol 1979;15:223-8.

18 Moss AJ, Glaser W, Topol E. Atrial tachypacing in the treatment of a patient with primary orthostatic hypotension. N Engl f Med 1980;302: 1456.

(Accepted 18 December 1980)
ONE HUNDRED YEARS AGO SIR,-Without entering into the merits of the question raised by Dr Markham on the earlier cases quoted by him (whose parallelism to the later case appears to me to be destroyed by the exceptions he himself makes), I cannot but think the whole argument turns upon the point as to what constitutes a medical consultation.

Homœopathy, in the eyes of all good men and true, is a thing as much outside legitimate medicine as astrology, alchemy, or the Brunonian system. The "gibberish," as Dr Johnson called it, by which such theories were represented, is a term equally applicable to the phraseology used in support of the modern assumption of "similars." How then, it may be asked, can the physician be said to "consult" with men who have neither language or ideas in common with him?

What Dr Quain did, in conformity with the advice of friends best able to help him, was to prove that Dr Kidd was not a homœopath. Dr Kidd's letter positively declared the fact, the first consultation verified it, and the bulletins, which were the result of subsequent consultations, confirmed the honesty and truth of Dr Kidd's declaration; but, even if Dr Kidd had turned out to be an inveterate homœopath, it might have been possible to put Dr Quain honourably in possession of the case. Although the issue was not tried, the power existed of eliminating Dr Kidd altogether. In such a case, the patient would have to exercise the power.

Your correspondent who signs himself "A Member" asks: "Is an ordinary practitioner justified in refusing aid in a dangerous case of labour, where a homoopathist professed is in attendance ?" In answer, let me put a hypothetical illustration. Suppose Mr Gladstone, in his late serious illness, had been first attacked in a railway-carriage, and that a homoopathic gentleman, travelling in the same carriage, and calling himself a physician, had been invited to take charge of the case until the Prime Minister could obtain the services of his own physician. What would Dr Andrew Clark, on arriving at the patient's bedside, have done with the homœopathic gentleman ? Assuredly, one of two things must have happened. If the homœopath were honest, and at once confessed his creed, $\mathrm{Dr}$ Clark would simply have ignored him as a medical practitioner. If this revelation were delayed, and the unwelcome truth elicited at a later period, the homœopath would probably have been summarily and ignominiously dismissed. Under either circumstance, professional honour would have been vindicated. -I am, etc, HenRY Dayman. (British Medical fournal, 1881.) 